\title{
Neither Sheep nor Peacocks: T. O. Elias and Post-colonial International Law
}

\author{
C. L. LIM*
}

\begin{abstract}
This article takes as its starting point the characterization of T. O. Elias as a representative of a 'weak' form of anti-colonial scholarship. Elias had sought to show that the ancient African kingdoms had participated in international legality with European states on an equal footing. The view has arisen in contemporary scholarship that this mode of argumentation is typical of the weak strain, evincing only a continued tendency to underestimate the imperial nature of international law itself. A related criticism is that many Third World scholars like Elias view international law's claim to universality and its ability to be inclusive as relatively unproblematic concepts. This article presents two interlocking claims. First, that while Elias was persuaded by the idea of a universal legal order derived from European thought, he never accepted the European view of universality. Vitoria and Grotius had paved the way for the idea of a universal legal order, but, as Elias was consistently aware, the extension of the European law of nations to Africa and Asia in the name of universality was unaccompanied by theoretical recognition in European legal thought that such universality cannot be unilaterally achieved on specific cultural terms. Second, that Elias did not view universality as an unproblematic concept. While he considered the legal order inherited from the European law of nations never to have been universal in its application, the post-colonial legal order could in principle approximate more closely to an ideal of democratic universality. We focus on Elias's attempt to substitute the doctrinal requirement of individual, sovereign consent with majoritarian lawmaking based on democratic theory, and his faith in the machinery of the United Nations as a 'technology' which post-colonial states would employ to put democratic majoritarianism into practice.
\end{abstract}

\section{Key words}

consent; critical race theory; T. O. Elias; post-colonialism; TWAIL; universality

\section{INTRODUCTION}

Taslim Olawale Elias's discussion of the nature of African societies provides a useful lens through which we might assess his scholarship on the evolving post-colonial international legal order. In The Nature of African Customary Laws we are treated to a vivid, entertaining dispute between Elias and two or perhaps three schools of thought about the nature of African societies, and the nature of 'the African'. ${ }^{\mathrm{I}}$ According to one 'extreme view' characterized by Hartland, the African 'never seeks to break forth'. ${ }^{2}$ The African is, in other words, a sheep according to this view, or, as re-characterized by Elias, 'a robot'. Yet, as Elias argued, '[t]he regularity and apparent

\footnotetext{
* Professor of Law, University of Hong Kong, Hong Kong S.A.R., People’s Republic of China; cllim@hku.hk.

I T. O. Elias, The Nature of African Customary Law (I 956), 92-5.

2 Ibid., citing E. S. Hartland, Primitive Law (1924), I38.
} 
passivity with which he observes the norms of social and political life must not be taken as an indication that he cannot or will not do otherwise'. Another view, which Elias attributes to Malinowski, is of the African as a 'real peacock', 'nothing if not boastful, arrogant and self-assertive'. ${ }^{3}$ But Elias also considered that 'such a pessimistic view of human nature stands contradicted by the realities of African society'. ${ }^{4}$ In Elias's view, therefore, the African and African society are ill-described by both the 'sheep' and 'peacock' theories.

When we come to consider Elias's views about the international legal order, we find that Elias considered the new African states, too, to be neither peacocks nor sheep. They would be absorbed into what was once a European international legal order, something which at the same time presents certain distinct challenges to be overcome. But if a Eurocentric view were discarded from the outset of the inquiry, it would become plain that the sorts of treaty practice and legal rules regulating diplomatic intercourse were present even among the ancient African kingdoms. Such African legal intercourse was sufficiently similar to the European law of nations. As a result, Elias, unlike Álvarez's Creole world view, did not place much theoretical importance on the distinctiveness of 'African international law'. ${ }^{5}$ Elias did not seek to make peacocks out of the newly decolonized African states but sought to equate African international law practice with its European counterpart. What he sought was parity with the European law of nations on the basis of 'sameness', not 'difference'. Presumably this was due to Elias's appreciation of the fact that the Asians and Africans, as in the earlier case of the Amerindians, were originally considered 'unequal' precisely because they were considered so 'different'. ${ }^{6}$ As such, a peacock theory would be somewhat ill-suited to dispel the cultural superiority thesis insofar as that thesis depended largely on cultural differences. However, the newly emergent African states should not be considered sheep either, by virtue of their inclusion (and desire to be included) within a new post-colonial international legal order. Acceptance by the African states of the post-war international legal order was

3 The words are Elias's own, citing B. Malinowski, Crime and Custom in Savage Society (I926), 30.

4 Elias, supra note I, at 94.

5 See L. Obregón, 'Noted for Dissent:The International Life of Alejandro Álvarez',(2006) I g LJIL 983, at 989. What Elias shared with Creole consciousness was the basic need for acceptance and inclusion in the international legal order. This juxtaposition of an absent emphasis on particularity coupled with an emphasis on the 'sameness' of African and European international law presented, as I argue below, much cause, together with Elias's belief in the possibility of true universality, for the misunderstanding that he simply apologized for the international legal order.

6 For the two conceptions of equality see P. Hughes, 'Recognizing Substantive Equality as a Foundational Constitutional Principle', (I 999) 22 Dalhousie Law Journal 5, at 38-49, and G. E. Devenish, A Commentary on the South African Bill of Rights (1999), 43-9. For the application of equality as 'difference' to transnational problems, celebrating locally contingent perspectives, see A. Anghie and B. S. Chimni, 'Third-World Approaches to International Law and Individual Responsibility in Internal Conflicts', (2003) 2 Chinese Journal of International Law 77, at 83; V. Nesiah, 'Toward a Feminist Internationality: A Critique of US Feminist Legal Scholarship', (I993) I6 Harvard Women's Law Journal I89. In a sense, I am making no judgement here about whether equality as difference or as sameness is the more progressive notion. While observing that the literature tends to pay attention to local, contingent truths - in other words 'difference' - as progressive discourse, I mean only to indicate that Elias does not place much emphasis on this. Having said that, it has been noted that 'difference' discourse may also be regressive; see C. MacKinnon, Feminism Unmodified: Discourses on Life and Law (I987), 39, which attacks the discourse of 'difference' in C. Gilligan's work: C. Gilligan, In a Different Voice: Psychological Theory and Women's Development (1982). 
never, and ought not to be, considered total surrender to the cultural premises of European legal thought.

This article presents two interlocking claims. First, while Elias accepted the idea of a universal legal order derived from European thought, he never accepted universality on European terms. Vitoria and Grotius had paved the way for the idea of a universal legal order, but what Elias had tried to show was the existence of universality in practice - that is, extending to the practice of the African kingdoms without its due theoretical recognition in European legal thought. ${ }^{\text {Second, the }}$ lingering impression today that Elias and his generation saw universality as something unproblematic is misplaced. Such an impression confuses what Elias aspired to - true universality both in theory and practice - with what he appreciated to be the present state of international law. The legal order inherited from the European law of nations is not truly universal, but it could be. For Elias, colonialism and its after-effects could be addressed with more progressive forms of international law doctrine resulting from greater participation by the African and Asian states in the international law-making process. ${ }^{8}$

In this article I attempt to address Elias's ideas and also the tensions within them. I dwell on Elias's attempt to replace the requirement of individual consent in liberal legal doctrine with majoritarian law-making based on democratic theory, and on his faith in the machinery of the United Nations as a 'technology' which post-colonial states could employ to put democratic majoritarianism to the practical work of reforming that legal order. For Elias, the immediate post-colonial international legal order was an extension of the old European legal order, but the new UN legal order would be truly universal.

\section{SOVEREIGNTY AS EMANCIPATION, THE LEGISLATIVE REFORM THESIS, AND ELIAS'S SYNTHESIZING SCHOLARSHIP}

Assuming that the European cultural superiority thesis could be dispelled, attainment of sovereign statehood would complete the process of post-colonial rectification by according the capacity to make and change international law. Following statehood, post-colonial states would preserve those aspects of the international legal order that guaranteed their status by guaranteeing their hard-won sovereignty, whereas the concomitant law-making and law reform powers which they possessed would enable them to repeal those doctrines that continue to repress and subjugate. ${ }^{9}$ The link between sovereign independent personhood and law-making power is therefore an especially important one. As Anand points out in relation to the Asian states' 'having lost their personality' during colonization, Asian states

7 Requiring a standard of civilization to be met as a precondition to membership of international society is not what true, theoretical, universality is about; see, e.g., the discussion of Vitoria in G. W. Gong, The Standard of Civilization in International Society (I984), 36-7, and H. Bull's brief remarks on Grotius and Vitoria, ibid., at vii (Foreword).

8 T. O. Elias, Africa and the Development of International Law(I972), 46-6r; T. O. Elias, New Horizons in International Law (I992), 29-I52.

9 Citing S. P. Sinha, New Nations and the Law of Nations (I967); J. Gathii, 'International Law and Eurocentricity', (I998) 9 EJIL I84, at I90, citing S. P. Sinha, New Nations and the Law of Nations (I 967). 
'could not play an active role in the development of international law during the most creative period in its history'. ${ }^{\text {IO }}$

Thus seen, dispelling the notion of Afro-Asian cultural inferiority was critically important. The example of east Asia, and especially the case of Japan, presents a well-known illustration. Japan's original aim in seeking mastery of the European law of nations was not decolonization as such or even statehood, but status as a 'civilization' as understood in the Western European sense. Japan sought to establish itself as a 'civilized' power by waging its own imperial campaigns in accordance with the European laws of war. As Japan understood it, civilized warfare was the hallmark of a civilized nation and, in this way, it eventually secured recognition of its sovereignty. ${ }^{\text {II }}$ Thus seen, recognition was never truly considered simply to be declaratory for countries of the non-Western world like Japan. If the Japanese lesson was anything to go by, recognition as a civilized nation was constitutive of international personhood. For Elias and his generation, the situation had not changed markedly in the post-war world which they inherited; it remained important to convince the West that the newly independent states of Africa and Asia were equal in cultural, historical, racial, and ethnic terms.

In practice, the Afro-Asian states, too, sought to do the same, with perhaps only a small caveat. What they could not do to convince they could at least try to compel through sheer voting strength. It became important to address head-on the prevalent view that colonial peoples were entitled to self-determination only insofar as they were prepared for it. ${ }^{\text {I2 }}$ This was what paragraph 3 of General Assembly Resolution I 5 I 4 of I 960 - the year which witnessed I 7 new states, I 6 of which were African, becoming members of the United Nations - was about. Paragraph 3 stated categorically that 'inadequacy of political, economic, social or educational preparedness should never serve as a pretext for delaying independence'. ${ }^{13}$ Independence had thus become the only option and no conditions were to be attached as part of a process for its attainment. The central tenet of Resolution I5I4 - that colonial peoples were in this sense immediately entitled to unconditional self-determination - constituted 'an attempt to revise the Charter in a binding manner'. ${ }^{4}$ Together with the attempt to

Io R. P. Anand, New States and International Law (I972), 20. As we shall see, Elias believed that the extensive law-making accompanying the post-colonial period was at least comparable, if not more extensive.

I I There is a vivid account of this in R. P. Anand, Studies in International Law and History: An Asian Perspective (2004), 24-I02. See also the short remarks in Y. Onuma, 'Japanese International Law' in the Prewar Period Perspectives on the Teaching and Research of International Law in Prewar Japan', (I986) 29 Japanese Annual of International Law 23, at 29.

I 2 In practice, however, the device used in the post-war period to delay decolonization was no longer the League of Nations' notion of a sacred trust to ensure the gradual development of 'such peoples' who were 'not yet ready to stand by themselves under the strenuous conditions of the modern world' (Article 22(I), League of Nations Covenant, 28 June I9I9), but the more modern, UN Charter-based, concept of domestic jurisdiction under Article 2(7) of the Charter. See, e.g., the arguments presented by France in relation to the French North African possessions of Morocco, Tunisia, and Algeria in H. A. Wilson, International Law and the Use of Force by National Liberation Movements (I 988), 63 ff.; R. Higgins, The Development of International Law through the Political Organs of the United Nations (1963), 94-6.

I3 Declaration on the Granting of Independence to Colonial Countries and Peoples, UN Doc. A/RES/I5I4(XV) (I4 December 1960). Cf. UN Doc. A/RES/I54I(XV) (I5 December I960).

I4 See M. Pomerance, Self-Determination in Law and Practice (I 982), 9-I3 (emphasis in the original). 
construct a New International Economic Order (NIEO), ${ }^{15}$ this became one of the key examples of the use of General Assembly resolutions to emancipate the Afro-Asian world through post-colonial law reform.

However, progress in the socio-economic field, human rights (and particularly economic, social, and cultural rights), reform of the principles of international economic law, the attainment of full self-determination, and the enjoyment of sovereign independence were all interconnected. What was required, therefore, was not simply independence but an entirely new corpus of international legal norms by which these several aspirations could be met. Sovereignty and political selfdetermination would have been no more than an empty legal form if substantive self-determination - that is, economic development - and, in the social sphere, the anti-racist and anti-apartheid programmes were not also achieved. ${ }^{\mathrm{I}}{ }^{6}$ The ultimate aim was to become the attainment of economic and social justice.

While scholars such as Asamoah and others focused on General Assembly lawmaking as a new law-making instrument, ${ }^{17}$ others such as Anand, Prakash Sinha, and Abi-Saab focused on the succession of the new states to colonial legal obligations. ${ }^{18}$ Another phase of scholarship followed, with scholars such as Bedjaoui, Hossain, and others focusing on the reform of international economic principles. ${ }^{\mathrm{I} 9}$ The new legal principles of self-determination that emerged during the decolonization period, as with the reform of international economic law principles, did not truly receive full critical reflective attention until the late I970s, since self-determination was for some time, even following the adoption of the UN Charter, considered

Resolution on Permanent Sovereignty over Natural Resources, UN Doc. A/RES/I803(XVII) (I4 December I962); Declaration on the Establishment of a New International Economic Order, UN Doc. A/RES/320I(S-VI) (I May I974); Charter on Economic Rights and Duties of States, UN Doc. A/RES/328I(XXIX) (I 2 December I974).

I6 For Elias's attention to these issues, see, e.g., Elias, New Horizons, supra note 8, at I70-I, I79-82, I85-249; Elias, Africa, supra note 8, at 20I-20.

I7 This continued, however, an already well-established interest in the subject - see F. B. Sloan, 'The Binding Force of a "Recommendation" of the General Assembly of the United Nations', (I948) 25 British Yearbook of International Law I; D. H. N. Johnson, 'The Effect of Resolutions of the General Assembly of the United Nations',(I955-6) 32 British Yearbook of International Law97; O. Asamoah, 'The Legal Effect of Resolutions in the General Assembly',(I 964) 3 Columbia Journal of Trasnational Law 2 Io; B. Sloan, 'General Assembly Resolutions Revisited (Forty Years Later)', (I 987) 58 British Yearbook of International Law 39. Asamoah's contribution was to shift attention from talk of the legally binding nature of Assembly resolutions to their legal effect. He saw the latter as a wider legal-conceptual category which subsumed narrower talk of legal bindingness within it, whereas most (Western) scholars at the time considered the Assembly to have a very limited role. The most progressive among those who held this limited view was perhaps Blaine Sloan, who saw Assembly resolutions as having the propensity to fill gaps in law-making authority, but no more than that, whereas scholars working on other subjects, such as the law of territory, focused on such specific questions as whether 'directive' resolutions couched in the language of a 'recommendation' required the obedience of administering states, and whether such obedience can be characterized as a (mere) 'good faith' obligation to follow such recommendations; R. Y. Jennings, The Acquisition of Territory in International Law (1963), 83, and see generally $82 \mathrm{ff}$. Others, including liberal progressives such as Dugard, continued to be sceptical of the legal bindingness or effect of Assembly resolutions; see C. J. R. Dugard, "The Organization of African Unity and Colonialism: An Inquiry into the Plea of Self-Defence as a Justification for the Use of Force in the Eradication of Colonialism', (I967) I6 ICLQ I57, at I74-6. See also the works cited in Asamoah, 'The Legal Effect', at 2I 5-I6.

I8 Anand, supra note Io; S. P. Sinha, 'Perspective of the Newly Independent States on the Binding Quality of International Law', (1965) I4 ICLQ I28; G. Abi-Saab, 'The Newly Independent States and the Rules of International Law', (I962) 8 Howard Law Journal 95.

I9 M. Bedjaoui, Towards a New International Economic Order (I979), I Io; K. Hossain, 'Introduction', in K. Hossain and S. R. Chowdhury (eds.), Permanent Sovereignty over Natural Resources in International Law (I984). 
to be governed by political precepts, not legal principle. Indeed, the legal right to immediate self-determination was put into practice by the Afro-Asian lobby in the General Assembly ahead of its scholarly justification..$^{20}$ Elias was at the very forefront of such scholarship. ${ }^{2 \mathrm{I}}$ But he also stood out, with an array of complex but clear and systematic lines of thought, as a great synthesizer.

Unlike colonial $^{22}$ - and post-decolonization ${ }^{23}$ - self-determination scholarship, Elias's concern with synthesis placed the principle of self-determination firmly within the wider context of the reformist agenda of the new Afro-Asian states and the question of forming a just, universal legal order. ${ }^{24}$ Self-determination, traditionally seen as a mere prelude to sovereignty, therefore came to replace sovereignty as a central, organizing principle. This doctrinal reorientation put Elias in good, progressive company through the creation of new, overlapping scholarly agendas. ${ }^{25}$ He was, as we shall see, particularly impressed with what Philip Jessup, Clarence Wilfred Jenks, Wolfgang Friedmann and Richard Falk were each trying to do in the field. ${ }^{26}$

Elias's own writings focused first on the new forms of law-making and the applicability of the colonial legal rules in the post-colonial era, before turning to the reform of substantive rules and principles in furtherance of the legal right to economic and political self-determination. He sought to weave together the different strands. For him, the relations between these sub-fields of theory and practice were so intimately related that they constituted a comprehensive strategy for the reorientation and reform of the legal order. A concern to justify the legitimacy of General Assembly law-making and efforts to do away with the succession of colonial legal obligations

20 H. Gross-Espiell, Special Rapporteur, Implementation of United Nations Resolutions Relating to the Right of Peoples under Colonial and Alien Domination to Self-Determination, UN Doc. E/CN.4/Sub.2/39o and Corr. I and Add. I (22 June I977) and UN Doc. E/CN. 4/Sub. 2/405 (20 June I978); A. Cristescu, Special Rapporteur, The Historical and Current Development of the Right to Self-Determination on the Basis of the Charter of the United Nations and Other Instruments Adopted by United Nations Organs, with Particular Reference to the Promotion and Protection of Human Rights and Fundamental Freedoms, UN Doc. E/CN.4/Sub.2/404 (3 July 1978). One principal difference between Gross-Espiell and Cristescu's reports was that the latter did not consider self-determination to be a peremptory norm of general international law from which no derogation was permitted (i.e. as a jus cogens norm); see Pomerance, supra note I4, at I Io, noting this difference.

2 I Elias, New Horizons, supra note 8, at I 65-252 (these sections on self-determination and international economic law being closely interrelated); Elias, Africa, supra note 8, at 46-65 (the sections on the new states and on modern international law are closely related, and should also be read with the sections in New Horizons just mentioned). See also W. Ofuatey-Kodjoe, The Principle of Self-Determination in International Law (I977).

22 These pre-dated the emergence of a legal right to self-determination and were thus non-legal works: see, e.g., A. Cobban, National Self-Determination (1945).

23 See, e.g., Pomerance, supra note I4, at 7-I3; H. Hannum, Autonomy, Sovereignty and Self-Determination (I990); Antonio Cassese, Self-Determination of Peoples (I995). These were largely doctrinal works which focused primarily on the difficulties posed by secession and non-colonial claims to self-determination, questions about entitlement to non-colonial self-determination, and alternatives to independence (e.g. arrangements for autonomy).

24 Other legal works on colonial self-determination were either studies of state practice, or of related areas such as the law on the international acquisition of territory or statehood; see, e.g., A. Rigo Sureda, The Evolution of the Right of Self-Determination - A Study of United Nations Practice (I 973); M. Shaw, Title to Territory in Africa (I 986); J. Crawford, The Creation of States in International Law (I979).

25 In A. Anghie, Imperialism, Sovereignty and the Making of International Law (2005), at 197-8. Anghie lists Elias with Friedmann, Jenks, Röling, Anand, Fatouros, Abi-Saab, Castaneda, McDougal, and Falk in his discussion of scholars who saw the 'enduring effects' of colonialism not as a 'peripheral concern', but a 'central and inescapable issue for the discipline'. 
were all part of a 'second-level' theoretical effort to change the rules about how new rules were made, and to define the rules governing entry into, and participation within, the international legal order. As for what the substantive programme for reform would consist of, Elias emphasized self-determination as a legal right, the pursuit of economic justice as an aspect of economic self-determination, and the link between reform of international economic law principles and development. ${ }^{27}$

Many today say that the NIEO had failed. New doctrinal strategies continually emerged, so that persistent inequalities continued to thwart the legal order's promise of universality. Critics such as Anghie began to argue that these imperial and colonial strategies had been with us for a long time. Part of the problem, they say, lies in taking international law's promise of inclusivity and universality too literally, leading to a failure to observe international law's continued use as an instrument of subjugation. ${ }^{28}$ Drawing on Anghie's work, Danielsen recently argued that

It may be time for a new strategy - legal pluralism without the universalist cover a legal pluralism that respects and facilitates the proliferation of sovereignties, of norm-generating institutions, and of local, national, and regional experimentation and organized resistances to ready-made 'universals' and 'best practice' governance regimes. ${ }^{29}$

Instead of reforming the international legal order, says the critic and sceptic, first-generation scholarship such as Elias's should have resisted international law's universal claims in the first place. Seeking to reform the legal order tries instead to do too much and too little. The critic sees it as too little (i.e. no more than bordering on apology), ${ }^{30}$ while the sceptic sees it as too much (i.e. seeking to do the impossible). ${ }^{3 \mathrm{I}}$

\section{A NEW INDEPENDENT FORCE}

Elias's attempt to describe the ancient African kingdoms' familiarity both with the West and with international legality has been described as amounting simply to an attempt to achieve the 'spiritual rehabilitation' of the African. ${ }^{32}$ We might, with respect, disagree with this assessment. To be sure, Elias did not accept the historicaldoctrinal distinction between the European and Christian states and the 'uncivilized' Afro-Asian states, or a detached, autonomous and impartial international legal order, 33 but instead of continuing to emphasize the cultural aspects of the problem, Elias held liberal international law directly to its promise of guaranteeing

27 See the page references to Elias's writings, supra note 2I, as well as his remarks in New Horizons, supra note 8, at I33 (on minority rights, stability and economic development) for Elias's views on the links between the permanent sovereignty doctrine, the right to development, and the rights of minority peoples. D. Danielsen, 'Book Review', (2006) Ioo AJIL 757.

Ibid., at 762 .

Gathii, supra note 9, at 193.

Bedjaoui, supra note i9, at I Io.

Gathii, supra note 9, at 189.

See further the critique of the New Stream of International Legal Scholarship in the late I980s and during the I99os; M. Koskenniemi, From Apology to Utopia: The Structure of International Legal Argument (I989); D. Kennedy, 'A New Stream of International Law Scholarship', (I988) 7 Wisconsin International Law Journal I; the earlier, seminal work by Kennedy in D. Kennedy, 'Theses about International Law Discourse', (I980) 23 German Yearbook of International Law 353; N. Purvis, 'Critical Legal Studies in Public International Law', (I 99I) 
equality, independence, and autonomy to sovereign nations and peoples. ${ }^{34}$ It was this abandonment of the cultural project for a more familiar set of concerns about how international law is made and what the new principles of the legal order were, which, I suspect, has led to the misplaced notion that Elias somehow did not take the cultural project too seriously.

But Elias's purpose was to articulate a comprehensive programme for the remaking of the international legal order, and it is important to notice that while the 'spiritual rehabilitation' thesis was central, it was always only a part of his overall programme. His aim of 'spiritual rehabilitation' - indeed, Elias's entire interest in having a 'cultural project' - was simply a 'prelude' to sovereignty. 35 Sovereignty, in turn, was a mere precondition for a concerted effort to reform the international legal order. Taking liberal international legality seriously was important because this made the sovereign participation of the new sovereign, post-colonial nations of Asia and Africa important.

Elias's views on international law-making, sources theory, inter-temporal law, and the succession of the new African states to colonial treaty obligations illustrate a certain optimism about the potential of the newly independent Afro-Asian states to influence and remake the legal order. That became the principal preoccupation in his writings. ${ }^{36}$ Elias emphasized the successes of the Asian-African Legal Consultative Committee (AALCC) in having sought early on to address the question of the legality of nuclear weapons, as well as acting as an effective grouping during a host of other treaty conferences - the Vienna Conference on Diplomatic Relations in I96I, the I968 and I969 sessions of the Conference of Plenipotentiaries on the Law of Treaties in Vienna, ${ }^{37}$ and on the law of the sea, particularly in developing the idea of the exclusive economic zone. ${ }^{38}$ In sum, the AALCC had played an important role in directly or indirectly influencing the international law reform agenda roughly during the period from ig6o to I970.

Harvard Journal of International Law 8I; and also I. Scobbie, 'Towards the Elimination of International Law: Some Radical Scepticism about Sceptical Radicalism', (I990) 6I British Yearbook of International Law 339.

34 For this strategy see K. Crenshaw, 'Race, Reform, and Retrenchment: Transformation and Legitimation in Antidiscrimination Law', (I988) Harvard Law Review I33 I, at I368; C. L. Lim, Critical Race Theory, in Tim Murphy (ed.), Western Jurisprudence (2005), 383, at 393-5.

35 See section 6, infra.

36 It is arguably only in this regard that, conceptually speaking, Elias's project depended also on the success of the Afro-Asian initiative to remake the substantive rules of the international legal order, but at the same time it might be considered that here they enjoyed greater 'success' than in the international economic field. For an excellent account of the negotiating history behind the 'dual-regime' which the newly decolonized states following the Nyerere doctrine managed, with the help of Latin American delegations, to push through during the I978 Vienna Conference on the Succession of States in respect of Treaties, see Tai-Heng Cheng, State Succession and Commercial Obligations (2006), 79-I I 6. Under the dual regime, post-colonial states would generally have the 'clean-slate theory' applied to them with exceptions, while non-colonial successions would, in general, be governed differently; see Vienna Convention on the Succession of States in Respect of Treaties 1978, I946 UNTS 3, Articles I5-30. Among the developing countries, some, such as Malaysia, were lukewarm towards the clean-slate theory, at least in the context of the continued validity of devolution agreements. Malaysia subsequently scaled down its original positions, but was in any case outvoted; ibid., at 94-6.

37 Where he had also served as chair of the Committee of the Whole as well as of the Afro-Asian group.

38 Interestingly, Elias also recorded the opposition of members of the Asian-African Legal Consultative Committee to the trust concept which the major powers favoured, allowing them to exploit the ocean floor as part of the idea of the common heritage of mankind; see Elias, New Horizons, supra note 8, at 29-34 and 5I-2. 
Elias saw these partial successes, together with the initiative for an NIEO, as the basis for a new body of international development law which was also interrelated with a slew of other post-war law-making initiatives by the General Assembly and other, lesser, UN bodies. As he put it,

The new world order necessarily envisages clearer and bolder definitions of the rights and duties of States as between developed and developing ones than have hitherto been attempted or accepted in customary international law. The Declaration [on the New International Economic Order] and the Charter [of Economic Rights and Duties of States] reflect the new spirit that has been abroad underlying the Universal Declaration of Human Rights and the related covenants, the Declaration on Peaceful Coexistence and Friendly Relations, and that section of Part V of the Vienna Convention on the Law of Treaties which declares certain treaties invalid on certain vitiating grounds especially those treaties that conflict with a peremptory norm of general international law (jus cogens). A new world order seems truly to be in the making. ${ }^{39}$

In any event, such predictions gave Elias no cause to reject the international legal order. Following decolonization, the new landscape of a post-colonial international legal order appeared more clearly in tune with the aspirations of Third World nations. Third World solidarity would provide the Afro-Asian nations with a coherent strategy for repealing the legal remnants of the past, and he saw it as the role, function, and responsibility of the Afro-Asian states to effect the universalization of international law and its reformulation on an equitable plane. In addition to this forward-looking aspect, Elias's writings also evinced a restorative aspect. He was equally concerned with redressing the mistakes of the past by reshaping legal doctrine, hence his advocacy of a limited intertemporal law doctrine in relation to the question of territorial dispositions. ${ }^{40}$ On the question of treaty succession, too, if Elias was not wholly sympathetic to a clean-slate theory, he was at least against automatic succession to colonial obligations. Putting aside multilateral treaty obligations, when it came to affected third-state rights in bilateral treaties, Elias's preferred solution was negotiation with such affected third states. ${ }^{4 \mathrm{I}}$ But apart from such doctrinal refinements and hopeful predictions of the future, how was the practical aim of concerted reform of the legal order to be achieved?

\section{4. 'The Whole problem of Setting up A neW Device'}

Writing on the North-South divide in relation to the role and function of the International Seabed Authority, Elias observed that

The whole problem ... seems to hinge ultimately upon the setting up of a device or mechanism which must ensure, and be seen to ensure, the holding of the scales fairly between the understandable fears and apparently excessive precautions of the industrialized nations on the one hand and the equally understandable fears and apparently groundless scepticism of the developing nations. The former are afraid of

\footnotetext{
39 Ibid., at 27

40 T. O. Elias, 'The Doctrine of Intertemporal Law', (I980) 75 AJIL 285.

4I See Elias, Africa, supra note 8, at 22-3, citing the approach of the francophone African states in common with the Nigerian example, as against the examples of Tanganyika, Uganda, Kenya, and Malawi, which chose to phase out such treaty obligations on the expiry of a grace period.
} 
numbers, as their experience of the United Nations and its agencies has shown that they cannot, except in the Security Council, always have their own way ... Most of the latter have too recent experiences of colonization ... And, yet, representation on the central Council of the proposed International Sea-Bed Authority has to reflect the preponderance of numbers of developing States if the Authority is to have the chance of being acceptable to the majority of the world. ${ }^{42}$

In this regard Elias became exercised by the new theories of 'consensus lawmaking' in a 'tangled web of Soviet theories' - in particular, those of Tunkin, Morosov, and Yanovskii - on the question of General Assembly resolutions. Following McWhinney, ${ }^{43}$ Elias detected - in Tunkin's rejection of the formal law-making character of General Assembly resolutions, Yanovskii's insistence on unanimity, and Morosov's need for agreement between the communist and capitalist camps and the three main political groupings (communist, capitalist, and 'neutralist' or nonaligned) - some recognition among Soviet jurists of a newly emergent doctrine of law-making by 'consensus' ${ }^{44}$ In contrast, others in the socialist bloc - Pechota, for example - viewed Assembly resolutions as representing 'the developing juridical conscience of people'. In other words, you cannot ignore them. Falk, like Jenks, considered that therefore 'the opposition of one or more sovereign States' should not preclude the Assembly's emergent law-making capacity. Lachs considered that international society had begun to acquire limited legislative authority. ${ }^{45}$

In juxtaposing the two sets of views, Elias's own view was complex but clear. Consensus was not to be defined as the need to ensure that there was no dissent from any quarter. In a word, consensus is not the legal doctrine of consent but something else altogether. Call this 'new' view of law-making a 'consensus' view if you must, but note that one would use the term 'consensus' in a diplomatic sense differently from its strict legal-doctrinal sense. Elias used 'consensus' to mean the insignificance of the legal doctrine of individual consent (i.e. refusal to consent, or even outright dissent). Admittedly, he sometimes conveyed all this in a confusing manner, ${ }^{46}$ but the distinction between the diplomatic and legal senses was clear throughout in his writings. The new Soviet theories might well have described what multilateral diplomacy by consensus decision-making was about in practicethat is, the importance of non-dissent from any quarter - but, as a matter of law, requiring individual consent as a precondition for applying a new international rule was simply undemocratic. As Elias put it,

It would be dangerous to mix up the questions of the legal validity of [a majority vote] with that of its desirability or wisdom in any given context; the one is an extra-legal consideration, while the other is a matter of strict law. ${ }^{47}$

42 Ibid., at 75 .

43 E. McWhinney, 'The Changing United Nations Constitutionalism: New Areas and New Techniques for International Law-Making', (I967) 5 Canadian Yearbook of International Law 68, at 83.

44 Elias, Africa, supra note 8, at 70.

45 Ibid., at 7I. See also Filartiga v. Pena-Irala, 630 F.2d 876, discussing the status of the Universal Declaration of Human Rights in similar terms.

46 See the entire discussion in Elias, Africa, supra note 8, at 70-3.

47 Ibid., at 73 . 
Onuf had correctly pointed out that, democratic or not, the Western states would reject such loss of power to the global South. ${ }^{48}$ But as Elias saw it, it was not legal doctrine that precluded the new mode of General Assembly law-making. The legal doctrine that sovereign consent to a rule solely enables the opposability of that rule to the consenter was subscribed to by only a handful of Western states, and its validity was therefore confined only to the service of such narrow interests. Elias observed how these 'advocates of consent ... are also the first to insist that the three-quarters of the world that took no part in its formation must be regarded as bound by it, consent or no consent'. ${ }^{49}$ So much then for the importance of individual consent as legal doctrine.

Observe, however, that the Universal Declaration of Human Rights, the Declaration on the Granting of Independence to Colonial Countries and Peoples, the Charter of Economic Rights and Duties of States, the Declaration on Friendly Relations, the Resolution on Apartheid as an International Crime, as well as the two human rights covenants of I966, the Convention on the Suppression and Punishment of the Crime of Apartheid, and also the Genocide Convention, represented an explosion of UN-sponsored international law-making. Importantly, they had all been adopted democratically by being "preceded by several General Assembly debates ... based on the report or reports prepared by a study group or by one of the sub-committees set up by the General Assembly', before 'their formal adoption ... in a plenary session by a stipulated majority'. ${ }^{\circ}$ As for the Charter of Economic Rights and Duties of States, the new principles already 'reflect the emergence of new concepts regarding property and the state's right to nationalize', precisely because the 'sense of the emerging concepts, as evidenced by the series of resolutions adopted by the General Assembly with near unanimity of the community of states, is that property rights are no longer absolute'. ${ }^{\mathrm{I}}$

Ultimately, the practical setting for Elias's theory of democratic international law-making would be provided by the United Nations, and primarily the General Assembly. There the large numbers of Afro-Asian states would be able to exert themselves properly in the law-making field - and by majority rule if necessary. There were already several bodies, in addition to the newly emerging specialized bodies, that were being created at the behest of the Afro-Asian lobby, which he also saw as holding much promise in being put to the service of creating the technical rules which were necessary to address the legal minutiae of a universalist, postcolonial but increasingly complex regulatory legal order. ${ }^{2}$

On the side of the debate over the comparative efficacy of the different modes of international law-making, 53 Elias was also a strong believer in concerted, multilateral efforts at international law-making through the various treaty conferences and

Ibid., at 72 .

Ibid.

Elias, New Horizons, supra note 8, at 90-I.

Ibid., at 2 I I (emphasis added).

He was a particular fan of Wolfgang Friedmann's writings, and especially Friedmann's Changing Structure of International Law (I964), which he described in historical terms as 'epoch-making'; Elias, Africa, supra note 8, at 82 .

O. A. Elias and C. L. Lim, The Paradox of Consensualism in International Law (I998), I73-9I. 
General Assembly law-making, as well as through the specialized agencies. This, to him, was part of a new international legal technology. ${ }^{54}$ Compared with what he termed the 'somewhat sketchy character and content of international law-making in the pre-United Nations era' - in other words, customary law-making - the International Law Commission, which had been established by the General Assembly in I974 under Article I3 of the UN Charter, now provided an opportunity for the Afro-Asian states to participate on the basis of equality and common interest in restating, reforming and supplanting the existing legal order. As he says in Africa and the Development of International Law, the Commission would be composed of a membership drawn from 'various forms of civilizations and the principal legal systems in the world' - something that would ensure 'the universality of the legal rules and practices to be reflected in the [Commission's] draft articles'. ${ }^{55}$ The "primary purpose' of the General Assembly's establishment in 1947 of the International Law Commission, pursuant to Article I3(I) of the UN Charter, was to bring

international law up to date by a process of modifying existing rules to meet the needs of the newly enlarged international community. In this way, some serious effort is being made to take account of the expanding frontiers of international law. The keynote is the progressive development and codification of the subject, and in the discharge of that task there is to be ensured the widest possible participation, which includes the representatives of the newly independent States hitherto denied participation in the formulation of customary international law. ${ }^{56}$

In addition to such codification, progressive development, and multilateral-treaty law-making, 57 the newly independent Afro-Asian states had also placed increased pressure on creating specialized avenues and bodies that went beyond the public international law field; for example, for the harmonization and unification of private law. These new legislative methods were badly required, in any case, to meet the needs of a technologically more advanced, increasingly interconnected regulatory world. This was the theme of New Horizons, which Elias repeated elsewhere. ${ }^{5}$ How satisfying it must have been that the African (and Asian) states could now hope to lead the way in all the new international law-making institutions that would now be required. The idea that they should reject that legal order would have been ridiculous. It was to be, by virtue of having to provide for a fast-changing world, a vastly different legal order anyway, and which required the institutional arrangements dominated by the large numbers of Afro-Asian states in order even to generate a fraction of the

54 I am using the term 'technology' to denote an anti-positivist, anti-formalist, and pragmatic conception of international law as a mechanism of social engineering. See further A. Anghie, 'Colonialism and the Birth of International Institutions: Sovereignty, Economy, and the Mandate System of the League of Nations', (2002) 34 New York University Journal of International Law \& Politics 5 I3, at 578-579 (observing that the early twentieth-century linkage between law and institutions created 'a formidable set of technologies'). Anghie sees this as the eventual realization of Roscoe Pound's and Manley Hudson' vision of international law, see further M. O. Hudson, 'The Prospect for International Law in the Twentieth Century' (1925) Io Cornell Law Quarterly 4I9, at 428-436.

55 Elias, New Horizons, supra note 8, at 384-5.

56 T. O. Elias, United Nations Charter and the World Court (I989), I9-20.

57 See Elias, Africa, supra note 8, at 64-6.

58 Elias, supra note 56; see especially the Prefatory Introduction. 
new kinds of international rules needed. ${ }^{59}$ These new rules that were needed and the new, more participatory legal order were joined at the hip.

Elias traced the legal - indeed, constitutional - authority for generating these new types of norm to the Charter, not only under Article I3(I)(a), which concerned the General Assembly's role in the progressive development and codification of international law, but also taking into account Article I(3) and Article I3(I)(b) 'responsibilities, functions and powers' of the General Assembly, as well as Chapters IX and X of the Charter. In these last respects, the General Assembly was tasked especially with legal development and law-making in the economic and social fields. ${ }^{60}$ One example is the UN Commission for International Trade Law (UNCITRAL), a body established by the General Assembly as part of that broad authority on its part to create new international rules beyond the public international law field. ${ }^{6 \text { I }}$ Its purpose would be to 'further the progressive harmonization and unification of the law of international trade', ${ }^{62}$ and to serve as a universal body guided by the principle of equitable geographical distribution and having further regard to the need to represent nations committed both to free market principles and to central planning. ${ }^{63}$ Likewise, with the UN Conference on Trade and Development (UNCTAD) ${ }^{64}$ other ad hoc bodies such as the Committee on Principles of International Law Concerning Friendly Relations and Co-operation among States, and also the specialized agencies such as the International Labour Organization (ILO), the UN Educational, Scientific and Cultural Organization (UNESCO), the Universal Postal Union (UPU), the International Telecommunications Union (ITU), the International Civil Aviation Organization (ICAO), and the World Health Organization (WHO) $)^{65}$ would all serve the needs of regulation and standardsetting.

Finally, there was also the International Court of Justice. The General Assembly in Resolution I7I(II) of I4 November I947 had tasked the Court with the role of treating the General Assembly's resolutions, which would of course reflect the weight of Afro-Asian votes, as itself evidence of international law. ${ }^{66}$

59 As he saw it, this had to do with the 'new frontiers' of international law involving such 'new branches as international constitutional law, humanitarian law, law of the sea and of the air, international law of communications-in fact, a whole new range of specialized fields recently brought within the ever-expanding frontiers of international law'; ibid., at 85 .

60 Elias, New Horizons, supra note 8, at 386; Elias, supra note 56, at 19.

6I Elias, New Horizons, supra note 8, at 387.

62 UNCITRAL Statute, Article 8.

63 Elias, New Horizons, supra note 8, 387.

64 For the Third World's use of the Assembly to establish UNCTAD, at the expense of the UN Economic and Social Council (ECOSOC) in which the Third World had less control, and the consequent enlargement of Third World representation and influence in UNCTAD, see the first-hand account in S. M. Finger, American Ambassadors at the UN (I988), at I44-9. UNCTAD was the culmination of a new emphasis, starting in the I960s, on the part of the Third World states on the role of international trade in economic development.

65 See also Elias, Africa, supra note 8, at 67-8; see further the groundbreaking study in C. H. Alexandrowicz, The Law-Making Functions of the Specialized Agencies of the United Nations (I973).

66 UN Doc. A/RES/3232(XXIX) (I 2 November I974) as discussed in Elias, supra note 56, at 20-I. 


\section{A United Nations legal order based on 'Legitimacy', 'EFFECTIVENESS', AND 'DEMOCRACY'}

Unsurprisingly, Elias lionized the UN legal order. A recurring phrase of his, attributed to George Canning, was that the existence of the United Nations 'called a new world into existence in order to redress the balance of the old'. ${ }^{67}$ First, the post-war UN legal order introduced a new set of norms and institutions, which nonetheless put themselves to the service of guaranteeing the sovereignty, territorial integrity, autonomy, and self-determination of the Afro-Asian states. These principles promised to keep the brute practice of nineteenth-century Great-Power politics in check. In the past, the Great Powers had considered it their responsibility to transfer territories and peoples (i.e. as proxies for potential military might through conscription) from one sovereign to another whenever the power equilibrium was threatened. Similar thinking was applied to the carving up of colonial territories. But the Charter doctrines served to dishonour this Great Power practice by undermining the very ability of the post-colonial powers to carve out territories and peoples in this way. ${ }^{68}$ Prior to the emergence of the UN legal order, the principle of self-determination was applied selectively only to European territories and peoples, and to the Latin American continent. Africa and Asia, with the exception of the then Siam and Japan, continued instead to be subjected to a standard of civilization which they failed, and which enabled their continued colonial occupation.

While this tended to place great faith in the rhetorical strength of mere formal legal principles, it undoubtedly provided the growing number of Afro-Asian states with a coherent way of countering their own relative military, technological, and economic weakness and their marginalization by opposing arrangements such as the five permanent members (P-5) of the Security Council. ${ }^{69}$ On the institutionalorganizational front, the Afro-Asian states sought to shift the balance of institutional power within the United Nations from the P-5-dominated Security Council to their own superior voting power in the UN General Assembly.

To complete the Afro-Asian states' commitment to the United Nations, Elias exhorted them to embrace the organization's progressive agendas in the socioeconomic field, especially in human rights and development. To the extent that the United Nations heralded a new institutionalized, universalized international legality, it seemed that the Afro-Asian states were already making headway in this regard..$^{70}$ The Afro-Asian states had an especially important function in applying the new law-making opportunities which the UN framework provided, and in providing stewardship so far as the legislative agenda was concerned. Interestingly, identifying

67 Elias, Africa, supra note 8, at 48.

68 See G. Schwarzenberger, Power Politics (I94I), I25, as discussed further in H. Kleinschmidt, The Nemesis of Power (2000), at I 3 .

69 See, however, C. L. Lim, 'The Great Power Balance, the United Nations and What the Framers Intended: In Partial Response to Hans Köchler', (2007) 6 Chinese Journal of International Law 307.

70 For an assessment of coalition activity in the General Assembly during that period see, e.g., M. J. Peterson, The General Assembly in World Politics (I986), at 254-9 (although noting that the 'hard use' to which the Third World put the General Assembly also resulted in greater disappointment). For the Assembly's role, and through it the Third World's influence in establishing UNCTAD see Finger, supra note 64, at I44-9. 
the social and economic objectives of the United Nations as those of the Afro-Asian states themselves meant that those who would argue against the role of the AfroAsian states were against progress. They could not see that there were by then emerging new, necessary ways of thinking about old things, such as the manner in which international law is made - Elias referred to this as the 'cumulative' aspect of international law's evolution. And there were also old ways of thinking about new things, such as the adaptation of international law to new subjects - this Elias called the 'synthetic' aspect. ${ }^{\text {II }}$ An assault on the role of the new states, using the new UN machinery, would therefore be regressive, and amount only to the old, obsolete European law of nations. ${ }^{72}$

Yet, already, the West had tried to reduce the principles of the NIEO to the status of soft law. ${ }^{73}$ No amount of argument to point out that many of the principles were or are widely accepted by the vast majority of states could prevent the powerful Western states, whose interest lay in advancing the principles of neo-liberalism, from withholding their consent and throwing the legal quality of the NIEO into doubt. Elias's response was to ascribe to international society, qua society, a legislative function based on at least three theses - international legitimacy, effectiveness, and democracy. He cited Oscar Schachter for the view that legitimacy and effectiveness were important facets of international legality. For Elias, four hundred years of intraEuropean international law-making could not legitimately be foisted on the African states. Seeking to do so to three-quarters of the world would render international law not only illegitimate but also ineffective. As for democracy, Elias sought to distinguish Judge Jessup's remarks in the South-West Africa Cases (Second Phase). ${ }^{74}$ Those who vote for a General Assembly resolution would be bound by consent and estoppel, those who abstained would be bound by acquiescence since they did not cast a negative vote, while 'those that vote against the resolution should be regarded as bound by the democratic principle that the majority view should always prevail where the vote has been truly free and fair and the requisite majority has been secured'. ${ }^{75}$ The words emphasized here are especially important. This view depended on prior legal agreement between states or, in the case of General Assembly 'decisions', a two-thirds majority for important decisions under Article I8(2), and a simple majority under Article I8(3) for all other decisions. ${ }^{76}$ It puzzled Elias that despite these 'apparently clear provisions', doubt and dispute could nonetheless arise about the 'legal bindingness' of General Assembly decisions and other

7 I Elias, Africa, supra note 8, at 8I-84.

72 'On the contrary, there are some traditionalists who are still opposed to any form of "contemporary" international law, who are fighting a rearguard action'; Elias, Africa, supra note 8 , at 85 .

73 Texaco Overseas Petroleum v. Libyan Arab Democratic Republic, (I978) I7 ILM I. For an insightful study, using the example of the Libyan oil arbitrations, of the parallel difficulty of arbitration law's disciplinary bias towards preserving the sanctity of private law arrangements allocating property rights against public law intervention, see A. A. Shalakany, 'Arbitration and the Third World: A Plea for Reassessing Bias under the Spectre of Neoliberalism', (2000) 4I Harvard International Law Journal 4 I 9.

74 [I966] ICJ Rep. 6 (Judge Jessup, Dissenting Opinion).

75 Elias, Africa, supra note 8, at 73. In short, majoritarianism is sufficient for universal law.

76 Ibid., at 70 . 
similar methods for the new forms of concerted international law-making. ${ }^{77}$ For him, 'legal bindingness' would be the result of democratic legitimacy, not textual interpretation. ${ }^{78}$

In Elias's world view, much hinged therefore on the role of the General Assembly as a permanent diplomatic law-making conference, and its dominance by the AfroAsian states in the post-colonial era. He was also Kelsenian in his view that Article Io of the Charter meant that 'there is hardly any international matter which the General Assembly is not competent to discuss and on which it is not competent to make recommendations'. ${ }^{79}$

It is worth emphasizing again that these views, which are not wholly free from being theoretically unproblematic, ${ }^{80}$ would have had little practical effect had not the recent technology of UN law-making added a new mediating device by which the gaps between consent and consensualism, or majoritarianism and universality could be bridged in practice. Fresh devices such as the package-deal approach presented a possible way of shading away the difference between consent and consensualism, majoritarianism and universality. We do this by splitting up the contentious issues for the purposes of facilitating trade-offs between different configurations of majority-minority interests. In the end result, the theoretical tensions between 'unanimous or universal consent' and 'majoritarian consensualism' would be dissolved by the supervening technology of a democratic, parliamentary form of international law-making - a law-making form which, moreover, had become sorely needed to get through a full global legislative agenda if the needs of a modern international legal order were to be met.

\section{Non-REJECTIONISM, INTEGRATIONISM, AND UNIVERSALISM}

Today some scholars consider that Elias's scholarly enterprise did not go far enough or, worse, amounts to self-deception. I am referring to Professor James Gathii's views, for example. ${ }^{8 \mathrm{I}}$ While Elias, as we have seen, had tried to show that the

77 Ibid. Cf. Bruno Simma (ed.), The Charter of the United Nations (I994), at 320, for the view that the term 'decision' in Articles I 8(2) and I 8(3) refers to all types of General Assembly action. This would have the effect of judging all General Assembly action on democratic grounds alone if we were to apply Elias's view to it, while at the same time applying the voting majorities prescribed in Article I 8(2) and (3) to all forms of Assembly action.

78 Interestingly, this also represents a sharp break from the Third World-Soviet convergence of viewpoints. The Soviet view had been stated in categorical, textual terms in relation to Article Io of the UN Charter; see G. Tunkin, Theory of International Law (I974), quoting from the Memorandum of the Government of the USSR on the Procedure of Financing the Operations of the Emergency United Nations Forces in the Middle East and the United Nations Operations in the Congo, I5 March I962.

79 Elias, Africa, supra note 8, quoting from H. Kelsen, The Law of the United Nations (I950), at I 98-9.

80 Clearly, treaty law is firmly consensual, but for the variety of theories in addition to majoritarianism in respect of customary law formation, see Elias and Lim, supra note 53, at 29-33. Elias's position might best be characterized as 'intellectualist' and 'majoritarian' - i.e. majoritarian decision-making is required because of the important international social need for a legitimate, effective, and democratic method of modern international law-making that would account for the will of the majority of states. But for the view that the great majority of states may not be the most powerful component in international society, see A. K. Henrikson, 'Global Foundations for a Diplomacy of Consensus', in A. K. Henrikson (ed.), Negotiating World $\operatorname{Order}$ (I986), 217, at 238-9. Henrikson, in effect, points to the 'ineffectiveness' in practice of creating a powerful disaffected minority instead.

8I Gathii, supra note 9. Gathii's typology has been adopted elsewhere within the Third-World Approaches to International Law Movement, see Anghie, supra note 25, at I Io. 
ancient African kingdoms experienced an international life similar to that governed by the European law of nations, ${ }^{82}$ it is now said that such 'weak' post-colonial scholarship failed to appreciate international law's fundamentally imperialist and capitalist-materialist underpinnings. ${ }^{8}$ It seems that Elias had simply assumed international law's potential to generate progressive doctrines. Another important strand of criticism, which I have already discussed, is that scholars like Elias viewed international law's claim to universality and its potential to be inclusive as being relatively unproblematic. ${ }^{84}$

An important site of debate lies in and around the doctrine of sovereignty. According to this view, it was not sovereignty's seventeenth-century roots which shaped its contemporary significance, ${ }^{85}$ but nineteenth-century thought's division of the world into civilized and uncivilized states. ${ }^{86}$ This division in historic doctrine subordinated non-European peoples to European colonial rule. The result was that Christians and European states were vested with sovereignty, while others were not. ${ }^{87}$ But a cultural turn was required precisely because non-European peoples did possess the factual attributes of sovereignty, and thus some other justification had to be found for their subordination. Fortuitously, non-European, non-Christian peoples were culturally inferior, or backward, or, simply put, 'had no history. ${ }^{88}$

Anghie has argued that the legal idea of sovereignty and the idea of a universal legal order were not therefore only influenced by the colonial encounter, ${ }^{89}$ but that these ideas are central organizing ideas for the discipline of international law. ${ }^{90}$ The strategies of subordination embedded in these doctrines therefore lend themselves to systemic recurrence. ${ }^{9 \mathrm{I}}$ Questions have therefore arisen about whether Elias and his

82 Elias, Africa, supra note 8, at 3-33 and 43.

83 Gathii, supra note 9, at, I89.

84 Anghie and Chimni, supra note 6, at 84.

85 Cf. C. Harding and C. L. Lim, 'The Significance of Westphalia: An Archaeology of the International Legal Order', in Harding and Lim, Renegotiating Westphalia (I999), I.

86 See generally Gong, supra note 7. See further Anand, supra note I I, at 24-I02; Wang Tieya, 'International Law in China: Historical and Contemporary Perspectives' (I99I-II) 22 I Recueil des cours, at I95 (on the exceptional nature of unequal treaties).

87 S. N'Zatioula Grovogui, Sovereigns, Quasi-sovereigns and Africans (I 996), 49 and 96, as discussed in Gathii, supra note 9 , at 185 .

88 See Danielsen, supra note 28, at 759, discussing Anghie, supra note 25, at 59, originally published as A. Anghie, 'Finding the Peripheries: Sovereignty and Colonialism in Nineteenth Century International Law', (I999) 40 Harvard Journal of International Law I, at 28. In Anghie's account, it was not so much race and religion that he emphasized but culture and the 'civilizing mission' of the West. Having said that, he located the strategic move which shifted attention from possession of the attributes of sovereignty to possession of the necessary social institutions of a civilized society, such as Henry Wheaton's view that non-European peoples lacked legal institutions; see, e.g., Anghie, supra, at 24. Interestingly, in English legal theory this debate continued even into the late twentieth century, with criticism of the same prejudices in H. L. A. Hart's work; see A. Allott, The Limits of Law (I980), $49 \mathrm{ff}$.

89 Anghie and Chimni, supra note 6.

90 Anghie, supra note 88, at 8; see also Anghie, supra note 25, at 3.

9I From seventeenth-century legal naturalist philosophy to a positivist/sovereign-centric nineteenth-century theory of racial, cultural, and religious supremacy; a twentieth-century inter-war conception of international law and organization as a species of global administrative technology and expertise; the application through legal 'succession' of exploitative international economic 'obligations' in the post-war, decolonization, and immediate post-colonial eras, and the I980s-9os era of good governance reforms. See generally Anghie, supra note 25 . 
generation ended up subscribing to a flawed legal order by neglecting the centrality of the cultural project. ${ }^{2}$

We have seen that, for Elias, the cultural project was only a prelude to sovereignty. Post-statehood, the Third World project ceased to be primarily cultural in nature, and instead should focus on sources doctrine, treaty succession rules, and international economic principles, as well as larger questions of social justice, albeit in a manner which would allow these to remain disciplinary questions (i.e. doctrinal questions) for international law. At worst, the charge amounts therefore to saying only that Elias paid too much attention to doctrine. Granted, those who today may locate the problem in nineteenth-century cultural discourse and who view cultural counter-discourse as central to a Third World resistance strategy, are naturally to be discomfited by such diminution of the cultural project by Elias and others. Be that as it may, it would be wrong to think that, as a result, Elias somehow failed to grasp the racist underpinnings of the international legal order, or that he somehow dismissed international law's racism as a mere peripheral concern. What he sought most was a meaningful device for reform, and not simply the actual, historical basis for a tragic appreciation of the legal order..$^{93}$ Indeed, he assumed the contemporary order to be tragic, but he considered that even the very material and economic underpinnings of that order, such as the notion of absolute property rights, were capable of being transformed. ${ }^{94}$ To succeed, however, the classic theoretical-justificatory problem of imposing legal rules on non-consenting (Western) states would have to claim a central place on the agenda. We have seen that a central aspect of Elias's thinking was that both the rules about how international law is made and the rules about what it meant to be able to participate in law-making were susceptible to Afro-Asian influence. To the unwary, Elias's doctrinal preoccupations in this regard might simply be seen to be so much uncritical acceptance of the structures of conventional, liberal international legal discourse - but to Elias his efforts were hardly about the celebration of received doctrine, and familiar ways of talking about international law. They

92 Gathii, supra note 9, at I 87-92. This is a claim which I have not seen Anghie make. Indeed Danielsen's review of Anghie is critical of Anghie on this account: see Danielsen, supra note 28, at 76I-2, arguing instead for 'legal pluralism without the universalist cover' as against Anghie's continued belief in the possibility of a universal legal order. According to Anghie and Chimni, this 'first generation' scholarship was characterized by (i) its indictment of colonial international law for its role in the subjugation of colonial peoples; (ii) acceptance of the view that pre-colonial Third-World nations and peoples were not strangers to relations with European states and international law; (iii) the adoption of a 'non-rejectionist stance'; (iv) acceptance of the importance of the doctrines of sovereign equality and non-intervention; and (v) acceptance of the fact that political independence is insufficient for the achievement of substantive colonial liberation. See Anghie and Chimni, supra note 6 , at 80-2.

93 Without pushing the analysis too far, we might see it as a difference between the interest which the historicalhermeneutic disciplines have in symbolic interactions, and the focus of critical theory on emancipatory possibilities. It is interesting to note that in the original Harbermasian scheme, it was critical theory which was most concerned with the question of domination or power in human societies, and not the historicalhermeneutic disciplines' concern with the meaning of symbolic interactions. See the classification in J. Habermas, Knowledge and Human Interests (I97 I). So who has been more critical, Elias or his critics?

94 He never considered that law was merely part of the 'superstructure', but like the pioneer critical-race scholars, he clearly considered material poverty and economic subordination to be central organizing ideas in understanding the reality of the international legal order. Cf. A. Freeman, 'Antidiscrimination Law from I954 to I989: Uncertainty, Contradiction, Rationalization, Denial', in D. Kairys (ed.), The Politics of Law: A Progressive Critique (I 998), at 285; D. Bell, 'Brown v. Board of Education and the Interest-Convergence Dilemma', (I980) 93 Harvard Law Review 5I 8. 
were about transforming our familiar ways of thinking and talking about international law. Today's charge that Elias's 'non-rejectionism' amounts to 'weakness' was answered with a powerful vision of international law's authority which shifted attention from the shortcomings of a positivist, unanimous consent-based legal order to the question of majoritarianism and the demands of democratic legitimacy. ${ }^{95}$

\section{Conclusion}

Elias was not wedded to the success of a specific reform programme, such as the NIEO and the principles for the exploitation of the seabed - although of course he supported these. Put another way, it is unclear whether he would have thought that these alone, if they succeeded precisely as dominant Afro-Asian opinion might have wished, would have completed the need for a truly inclusive, integrated, and universal legal order. It was simply fortuitous that those who have suffered imperial and colonial subjugation were now in the ascendant. They would not simply be remaking a world legal order for themselves. A new, universal legal order should not be a partial order as before, but should be an impartial order. He saw worth in Friedmann's and Falk's work in particular. Both captured the essential normative requirements of a new universal order. In Friedmann, the functions of the discipline of international law came into clear focus; like Jenks, he emphasized interdependence and inter-culturalism as a hinge on which much would turn for the new legal order. ${ }^{96}$ In Falk, distinguishing partiality from impartiality became especially important. ${ }^{97}$ Elias's attraction to these views tells us something important about why he still thought universality possible. It would be possible in a world which has been totally reconceived and decoupled from our old ways of thinking about international law. His was a conditional acceptance of the idea of a universal legal order.

It therefore did not mean that, for Elias, the UN Charter would simply become a 'colour-blind' world constitution. ${ }^{98}$ The concerted action of the Afro-Asian and other states, and the triumph of progressive opinion, would still be required to combat racism and racial discrimination on an international, global level, as the concerted action of the Afro-Asian states would be required to advance the principles of the NIEO. Abstract, formal notions of equality and sovereignty would not be enough, as opposed to concerted legal reform. It was ultimately up to the Afro-Asian states to advance economic and social justice, and it was the importance of this task which, in turn, made it important to tailor the law-making capacity of the United Nations to their accomplishment. In terms of the classic, although perhaps apocryphal, legal-reformist choice between engaging in radical legal interpretative exercises and initiating legislative reform, ${ }^{99}$ Elias was clearly a strong believer in concerted,

95 For a scathing attack on the corruption of traditional, sovereign consent-centric diplomacy by the parliamentarist notions of American diplomacy see Harold Nicolson, The Evolution of Diplomacy (I954). Nicolson's views demonstrate just how radical Elias's subsequent views about global parliamentarism really were.

96 Elias, Africa, supra note 8, at 82. See further generally Friedmann, supra note 52 .

97 In particular R. A. Falk, 'New Approaches to the Study of International Law', (I967) 6I AJIL 477, which is also cited in Elias, Africa, supra note 8, at 82.

98 Cf. Gathii, supra note 9, at I9I, n. 23.

99 G. Calabresi, A Common Law for the Age of Statutes (I 982). 
programmatic, policy-driven reform of the legal order, taking race into explicit account and class and developmental differences into implicit account. ${ }^{100}$ Putting aside its nomenclature, contemporary critical race theory would have been nothing new to Elias. It would also have been curious were it true that he somehow failed to acknowledge the atrocities of which Third World sovereigns were themselves capable. Contemporary scholars have of course emphasized this aspect. Their view is that progressive international lawyers should lend their expertise to the various class, gender, ethnic, indigenous, and religious-based groups who find themselves continually subordinated within Third World states. ${ }^{\text {IOI }}$ Elias himself paid close attention to the question of minorities, ${ }^{\text {I02 }}$ and more generally, to problems of African governance. True, the views of his generation would have been further advanced by our own contemporary understanding of the complexity of rights, ${ }^{103}$ and by the theoretical work of critical race theorists and global critical race feminists. ${ }^{104}$ But I do not believe he would have found a fundamental incompatibility, as opposed to a mere difference in inter-generational professional sensibility, between the two projects. $^{\text {I05 }}$

His views on majoritarianism as a legislative device in international society may have been doubted in well-known judicial and arbitral pronouncements. In Texacov. Libya and the Advisory Opinion on the Legality of the Threat or Use of Nuclear Weapons, geopolitical spread has been considered to be of equal importance to the vote count in assessing the legal effect of certain well-known General Assembly resolutions. ${ }^{\text {I06 }}$ If it were left to Elias, however, he would have counted voting strength alone, and it seems he would have counted the votes, and particularly the abstentions, differently.

Elias would have considered his own work radical in his day. What he argued for was world government, a world legislature, and the sort of democratic rule-making which John A. Scali, US ambassador to the United Nations in 1973-6, dubbed a 'tyranny of the majority'. Elias considered it preferable to minority tyranny. ${ }^{\text {I07 }}$ The present state of affairs represents only an illegitimate sort of legal order because of its antagonism towards the opinion of the vast majority of states. It is also a relatively

Ioo In addition to his attention to minority rights as well as to racism and racial discrimination in interstate relations, Elias could not but have been aware that the sort of majoritarianism which he advocated, particularly in the economic sphere, advanced the view of three-quarters of the world but ignored the view of 80 per cent of world trade and investment; cf. Finger, supra note 64, at $23 \mathrm{I}$.

Ior See further M. wa Mutua, 'Why Redraw the Map of Africa: A Moral and Legal Inquiry', (I995) I6 Michigan Journal of International Law I I3; the other works cited by Anghie and Chimni, supra note 6, at 83; and the various essays in A. K. Wing (ed.), Global Critical Race Feminism: An International Reader (2000).

I02 He was interested in the colonial-historical causes; see, e.g., Elias, Africa, supra note 8, at 39.The discussion follows from his earlier work on African law; see Elias, supra note I, at I8.

I03 See J. Crawford (ed.), The Rights of Peoples(I 988). Elias, as we have seen, was primarily concerned with economic and social rights, particularly UN law-making and standard-setting in the economic and social fields in the post-decolonization era.

I04 See Wing, supra note Ior.

I05 For the view that 'TWAIL [Third World approaches to international law] is not new', see D. P. Fidler, 'Revolt against or from within the West? TWAIL, the Developing World and the Future Direction of International Law', (2003) 2 Chinese Journal of International Law 29, at 32.

I06 See Legality of the Threat or Use of Nuclear Weapons, [1996] ICJ Rep. 226 (Judge Schwebel, Dissenting Opinion); Texaco Overseas Petroleum v. Libyan Arab Democratic Republic, supra note 73.

I07 This followed the vote taken on the Charter on Economic Rights and Duties of States; see Finger, supra note 64 , at $23 \mathrm{I}$. 
ineffective order in the light of the need to legislate comprehensively for a complex range of newly emergent global economic and social issues. In such circumstances, wherein an interconnected and increasingly complex world required detailed legal regulation in hitherto unregulated or ill-regulated areas of international social life, rejecting the whole legal order for being no more than a mere colonial artefact would have sidestepped the whole issue. Instead, Elias concentrated his efforts on the social functions that an international legal order should perform, and there was a substantial normative element in his vision of a universalized legal order.

For a president of the International Court of Justice to have considered the international legal order to have been illegitimate and ineffective in the absence of majoritarian law-making made Elias a fierce radical progressive by the standards of his age and also ours. 